\title{
Effects of a 6-week Hike on Physical Activity Levels, Psychological Wellbeing and Quality of Life in Breast Cancer Survivors
}

Baumann FT ${ }^{1 *}$, Bieck $\mathbf{O}^{1}$, Strunk $\mathbf{M}^{1}$, Reimer ${ }^{1}$, Zopf EM², Bloch $\mathbf{W}^{3}$ and Han $\mathbf{S}^{3}$

${ }^{1}$ Department of Internal Medicine, Center of Integrated Oncology Köln Bonn, University Hospital of Cologne, Germany

${ }^{2}$ Exercise and Nutrition Research Program, Mary MacKillop Institute for Health Research, Australian Catholic University, Melbourne, Australia

${ }^{3}$ Department of Molecular and Cellular Sport, Institute of Cardiovascular Research and Sport Medicine, German Sport University, Germany

\begin{abstract}
Purpose: The aim of this study was to explore whether a 6-week hike along the Way of St. James can improve the physical activity levels and psychological wellbeing of breast cancer patients.

Methods: 45 breast cancer survivors who had completed their primary treatment were included in a nonrandomized, controlled trial. The intervention group $(\mathrm{IG}, \mathrm{n}=26)$ received an 8-week training plan prior to hiking over $840 \mathrm{~km}$ in 6 weeks. Physical activity levels, quality of life, anxiety and depression were assessed prior to the 8-week preparation period, as well as before, directly after and 1 year after the 6-week hike. The control group (CG, $n=19)$ received no intervention.
\end{abstract}

Results: Physical activity levels increased significantly during the entire study period in the IG $(P=0.01)$ but not in the CG. The physical activity levels of the IG were significantly higher than in the CG both after the 8-week training and after the 6-week hike. Furthermore, the IG experienced significant improvements in several quality of life outcomes, as well depression and anxiety both during and after the hike. Significant group differences were observed primarily during the hike.

Conclusion: Long hikes have the potential to sustainably improve the physical activity levels as well as psychological wellbeing and quality of life of breast cancer survivors. Randomized controlled trials are necessary to confirm whether long hikes may be an effective rehabilitation strategy for breast cancer survivors.

Keywords: Breast cancer; Level of activity; Physical activity; Hiking; Quality of life

\section{Introduction}

Worldwide, approximately one million breast cancer diagnoses are made every year [1]. It is estimated that, in Germany alone, 71.900 women and 700 men will be diagnosed with breast cancer in 2018 [2]. A significant number of these patients will experience disease- and treatment-related side-effects for many years after their breast cancer diagnosis. Almost 50\% of breast cancer patients report suffering from anxiety one year after their diagnosis; after 2 years it is still 25\% [3]. Long-term occurrence of cancer-related fatigue after breast cancer has also been confirmed in various studies [4].

The frequently observed reduction in physical activity levels in breast cancer survivors may play an important role in this context. Due to the psychological consequences of the diagnosis, the physical side effects related to medical therapy, and/or the physical activity restrictions still imposed by some clinicians, many patients are uncertain about what kind of activities they can perform or become unmotivated. Those affected often withdraw from social interactions and become increasingly inactive. The physical inactivity results in a loss of physical performance and discomfort [5-8]. 30\% of all patients diagnosed with breast cancer are less active than before their diagnosis [9] and only $32 \%$ meet the current exercise guidelines [10]. Inactivity can also cause or exacerbate psychological problems $[7,8]$.

The positive effects of physical activity, including endurance training, on breast cancer patients have been confirmed in many studies [11,12]. However, the effects of hiking, which can be classified as an endurance exercise $[13,14]$, have rarely been assessed, especially in the oncological setting. The aim of this study was to explore whether a long hike can sustainably improve the physical activity levels and psychological wellbeing of breast cancer patients.

\section{Materials and Methods}

\section{Study design}

This study was a prospective, controlled and non-randomized intervention study. Its main objective was to improve the psychological element of self-trust in breast cancer survivors through a major challenge, such as hiking along the Way of St. James. We hypothesized that this would be accompanied by an increase in physical activity levels (primary endpoint) and a reduction in anxiety and depression. To determine whether changes would sustain, patients were followed for one year. The study ran for a total of 18 months and took place from 2010 to 2012 .

The study was approved by the ethics committee of the German Sports University Cologne. All procedures involved in the study were performed in accordance with the ethical standards of the institutional and/or national research committee and the Declaration of Helsinki. Informed consent was obtained from all individuals prior to participating in the study.

*Corresponding author: Baumann FT, Department of Internal Medicine, Cente of Integrated Oncology Köln Bonn, University Hospital of Cologne, Germany, Tel: +0049-221-478-97185; Fax: +0049-221-478 97191; E-mail: freerk.baumann@uk-koeln.de

Received June 14, 2018; Accepted July 10, 2018; Published July 12, 2018

Citation: Baumann FT, Bieck O, Strunk M, Reimer N, Zopf EM, et al. (2018) Effects of a 6-week Hike on Physical Activity Levels, Psychological Wellbeing and Quality of Life in Breast Cancer Survivors. J Cancer Sci Ther 10: 156-161. doi: 10.4172/19485956.1000538

Copyright: ( 2018 Baumann FT, et al. This is an open-access article distributed under the terms of the Creative Commons Attribution License, which permits unrestricted use, distribution, and reproduction in any medium, provided the original author and source are credited. 
Citation: Baumann FT, Bieck O, Strunk M, Reimer N, Zopf EM, et al. (2018) Effects of a 6 Week Hike on Level of Physical Activity, Psychological Parameters and Quality of Life in Breast Cancer Survivors. J Cancer Sci Ther 10: 156-161. doi: 10.4172/1948-5956.1000538

\section{Subjects}

Patients were eligible to take part in this study if they had received a diagnosis of breast cancer, had completed their primary treatment, and received their initial diagnosis within the last 5 years. Patients were excluded if they had a severe psychological or cardiovascular disease, metastatic disease, or were unable to carry their hiking backpack. As part of the study preparation, all participants underwent a comprehensive health check and their physical performance was determined.

\section{Exercise intervention and measuring points}

One of the most famous hiking trails in Europe is the Way of St James. It consists of a network of paths that run in a star shape through many countries and lead to one destination: the Spanish pilgrimage site of Santiago de Compostela. One of the most frequently walked sections is the Camino Francés. It begins in St. Jean Pied de Port in southern France and ends in Santiago de Compostela, covering $810 \mathrm{~km}$ and approximately 10,000 meters of altitude difference $[15,16]$.

After travelling to St. Jean Pied de Port as a group, patients in the intervention group had six weeks to complete the path at their own pace. They were free to choose their walking speed, when and where they take a break, how far they walk every day and what accommodation they preferred to stay at. The only component of the trip that was scheduled in advance was the start and finish date of the hike and the airfares. Eight weeks prior to the start of the hike, the intervention group received a training plan to support their preparation. The plan included endurance and strength exercises as well as information about the optimal training heart rate range. The individuals target heart rate range (at approx. $2.0 \mathrm{mmol} / \mathrm{l}$ lactate) was determined based on a treadmill spiroergometry including lactate diagnostics . Over the eight week period, patients in the intervention group were encouraged to conduct three to five 30-60 minute endurance exercise sessions per week within their training heart rate range. In addition, patients were recommended to perform their strength, balance and flexibility exercises one to two times per week. The intervention group trained for eight weeks without supervision.

The baseline test (T0) was conducted prior to the 8-week preparation period. The second assessment time point took place just before the 6-week hike (T1), followed by a third assessment time point immediately after the hike In order to assess the sustainability of the potential effects, the patients were examined again after one year during which no interventions took place (T3). The control group received no intervention for the entire duration of the study. Patients were encouraged to continue their daily routine as usual and were examined at the same time as the intervention group.

\section{Assessments}

Patients in both groups completed a baseline questionnaire to determine anthropometric and sociodemographic data as well as information about patients' tumor stages and any medical treatments.

The primary endpoint (physical activity level) was assessed with the validated Freiburger questionnaire on physical activity ("Freiburger Fragebogen zur körperlichen Aktivität" (FFkA) German version) involving 12 questions about physical activity in daily life, leisure time activities and sports activities. All activities can be converted into the number of metabolic equivalent (MET) hours per week). For this study the overall activity score was determined [17].

Health-related quality of life (QOL) was determined with the EORTC (European Organization for Research and Treatment of
Cancer) Quality-of-Life questionnaire (QLQ-C30) and its breast cancer specific module BR23 [18]

To assess anxiety and depression, the HADS (Hospital Anxiety and Depression Scale) questionnaire was used.

\section{Statistical analysis}

Patient characteristics are presented as mean values \pm standard deviation. The independent t-test was used to assess differences between the intervention and control group with regard to age, height, weight and BMI. The Chi-square test was used to assess differences in time of diagnosis (months since diagnosis) and medical treatment (surgery, lymph node removed, radiation therapy, chemotherapy, antihormone therapy, antibody therapy). To test the distribution of the dependent variables the Kolmogorov-Smirnov test was used. To compare individual assessment time points within the groups, the Wilcoxon test was used (T3-Baseline, T2-T1, T2-Basline). For the intergroup comparison, a "Last observation carried forward" analysis was performed to adjust for missing data. The Mann-Whitney-U test was chosen to investigate differences between the groups (T3-Baseline, T2-Basline). The results are presented as mean values \pm standard deviation. The significance level is $\alpha=5 \%$. SPSS 25 (IBM Corp., Armonk, NY, USA) was used for the statistical analyses.

\section{Results}

45 breast cancer patients were recruited and allocated to either the intervention group $(\mathrm{N}=26)$ or the control group $(\mathrm{N}=19)$. Groups were balances at baseline with regard to most baseline characteristics (Table 1), however women in the control group had more lymph nodes removed and a higher percentage of women in the intervention group received antibody therapy. All patients in the intervention group completed the 6-week hike without experiencing any adverse events. 6 of patients in the intervention group and 12 of patients in the control group were lost to follow up after one year (T3).

\section{Physical activity level}

The intervention group showed a significantly higher activity level than the control group after the 8 -week preparation period $(\mathrm{p}=0.05)$ and after the 6-week hike ( $\mathrm{p}=0.04)$ (Figure 1$)$. The physical activity level of the intervention group increased significantly $(\mathrm{p}=0.01)$ over the entire study period (Baseline: 44.79 \pm 34.82 MET-hours/week, T1: 91.93 \pm 53.96 MET-hours/week, T2: 120.44 \pm 81.61 MET-hours/week, T3: $115.50 \pm 75.08$ MET-hours/week), while the control group, did not change their activity level over time $(\mathrm{p}=0.87$; Baseline: $67.42 \pm 42.95$ MET-hours/week, T1: 67.09 \pm 53.78 MET-hours/week, T2: 52.18 \pm 38.16 MET-hours/week, T3: 58.34 \pm 126.93 MET-hours/week) (Figure 2).

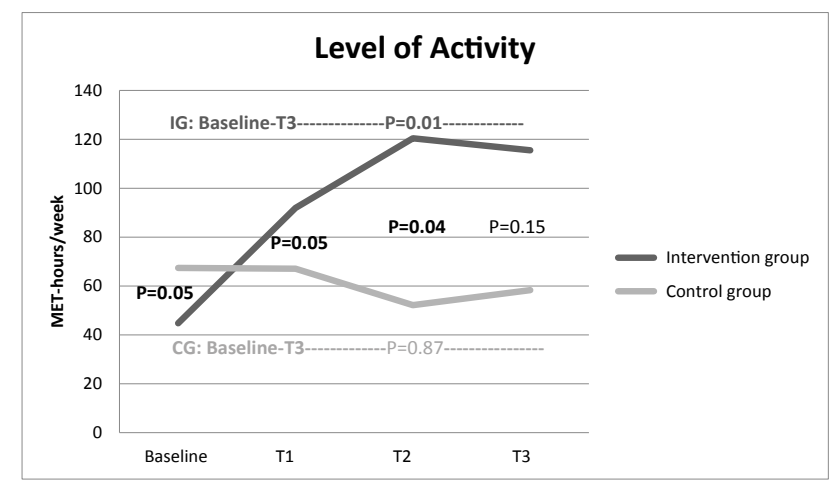

Figure 1: Development of activity levels in the intervention and control group. 
Citation: Baumann FT, Bieck O, Strunk M, Reimer N, Zopf EM, et al. (2018) Effects of a 6 Week Hike on Level of Physical Activity, Psychological Parameters and Quality of Life in Breast Cancer Survivors. J Cancer Sci Ther 10: 156-161. doi: 10.4172/1948-5956.1000538

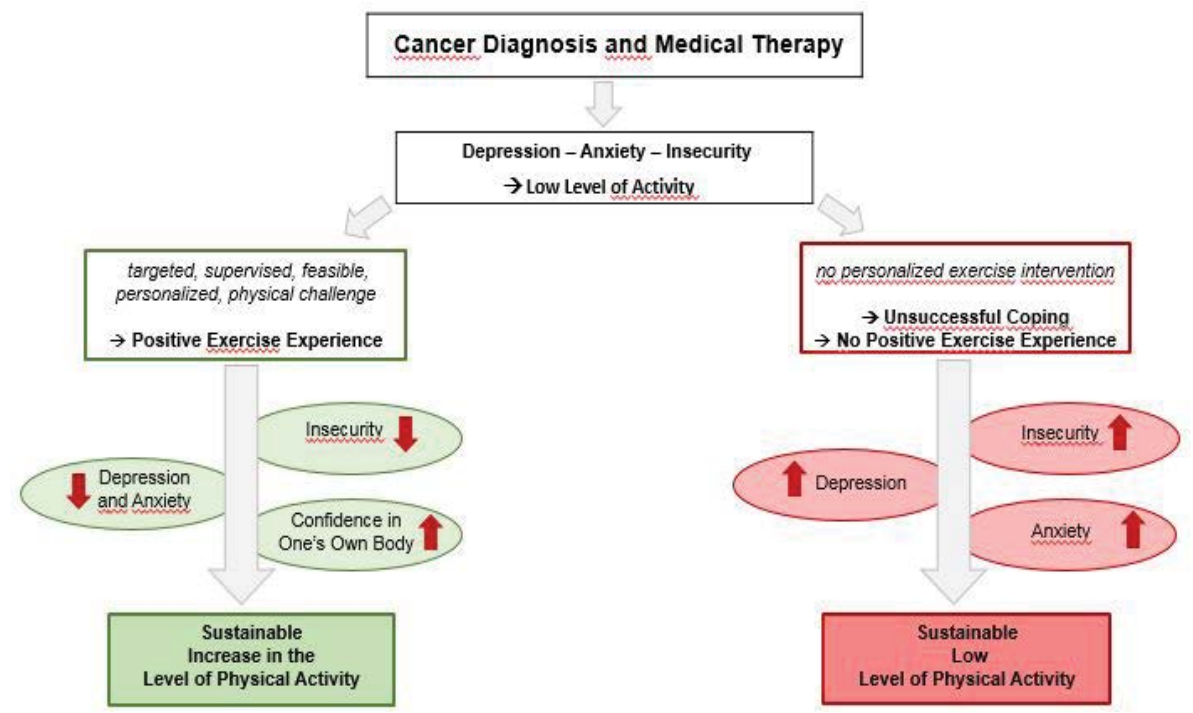

Figure 2: Potential consequences of cancer diagnosis on level of physical activity.

\begin{tabular}{|c|c|c|c|c|c|}
\hline & \multicolumn{2}{|c|}{ Intervention group } & \multicolumn{2}{|c|}{ Control group } & p-value \\
\hline Sample size $(\mathrm{N})$ & \multicolumn{2}{|c|}{26} & \multicolumn{2}{|c|}{19} & \\
\hline Age (in years) & \multicolumn{2}{|c|}{$52.8 \pm 7.2$} & \multicolumn{2}{|c|}{$51.8 \pm 10.2$} & 0.52 \\
\hline Height (in $\mathrm{m}$ ) & \multicolumn{2}{|c|}{$1.67 \pm 0.07$} & \multicolumn{2}{|c|}{$1.67 \pm 0.07$} & 0.98 \\
\hline Weight (in kg) & \multicolumn{2}{|c|}{$65.8 \pm 10.3$} & \multicolumn{2}{|c|}{$67.9 \pm 9.3$} & 0.38 \\
\hline BMI (in $\mathrm{kg} / \mathrm{m}^{2}$ ) & \multicolumn{2}{|c|}{$23.60 \pm 3.36$} & \multicolumn{2}{|c|}{$24.34 \pm 2.41$} & 0.32 \\
\hline Time since diagnosis (months) & \multicolumn{2}{|c|}{$21.9 \pm 12.4$} & \multicolumn{2}{|c|}{$31.1 \pm 16.4$} & 0.08 \\
\hline Medical treatment: & $\mathbf{N}$ & $\%$ & $\mathbf{N}$ & $\%$ & \\
\hline Surgery & 26 & $100 \%$ & 19 & $100 \%$ & 1.00 \\
\hline Lymph node removed & 10 & $38 \%$ & 18 & $95 \%$ & 0.01 \\
\hline Radiation therapy & 20 & $77 \%$ & 14 & $74 \%$ & 0.80 \\
\hline Chemotherapy & 19 & $73 \%$ & 15 & $79 \%$ & 0.65 \\
\hline Antihormone therapy & 13 & $50 \%$ & 13 & $68 \%$ & 0.27 \\
\hline Antibody therapy & 12 & $46 \%$ & 3 & $16 \%$ & 0.03 \\
\hline
\end{tabular}

Table 1: Baseline Characteristics of Patients in the Intervention and Control Group.

\section{Quality of life}

In the intervention group 13 EORTC QLQ-C30/BR23 quality of life subscales improved significantly during the hike (Baseline-T2): global quality of life $(\mathrm{p}=0.01)$, physical functioning $(\mathrm{p}=0.01)$, emotional functioning $(\mathrm{p}=0.01)$, cognitive functioning $(\mathrm{p}=0.05)$, social functioning $(\mathrm{p}=0.01)$, diarrhea $(\mathrm{p}=0.02)$, financial impact $(\mathrm{p}=0.02)$, body image ( $\mathrm{p}=0.01)$, future perspective $(\mathrm{p}=0.01)$, sexual functioning $(\mathrm{p}=0.01)$, systemic therapy side effects $(\mathrm{p}=0.01)$, arm symptoms $(\mathrm{p}=0.01)$ and breast symptoms $(\mathrm{p}=0.03)$ (Table $2 \& 3)$. While the improvements were particularly evident during the hike (T2-Baseline), some positive effects, such as physical functioning $(p=0.02)$, financial impact $(\mathrm{p}=0.01)$, body image $(\mathrm{p}=0.02)$ and future perspective $(\mathrm{p}=0.01)$, were sustained over the entire duration of the study. After the hike, a significant group difference (T2-Baseline) between the intervention and control group can be seen with regard to global quality of life $(\mathrm{p}=0.01)$, emotional functioning $(\mathrm{p}=0.01)$, financial impact $(\mathrm{p}=0.03)$, future perspective $(p=0.01)$, sexual enjoyment $(p=0.02)$, sexual functioning $(\mathrm{p}=0.01)$ and systemic therapy side effects $(\mathrm{p}=0.01)$. Notably, improvement in the BR23 scales, symptoms of the breast and symptoms of the arm, occurred despite the fact that patients were carrying their own backpacks during the hike some.

\section{Depression and anxiety}

In the intervention group depression $(\mathrm{p}=0.02)$ and anxiety $(\mathrm{p}=0.01)$ scores improved significantly during the hike (T2-Baseline) (Table 4). The results of the anxiety subscale remained significant in the intervention group up to one year after the hike ( $\mathrm{p}=0.04)$ (T3Baseline). There is a significant difference in depression $(p=0.05)$ and anxiety ( $\mathrm{p}=0.01$ ) between the groups during the hike (T2-Baseline).

\section{Discussion}

The aim of this study was to assess whether a 6-week hike along the Way of St. James can sustainably improve the physical activity levels and psychological wellbeing of breast cancer patients. To our knowledge this study is the first of its kind. The results show a significant increase in physical activity levels in the intervention group, as well as positive effects on depression, anxiety and quality of life [19-21].

A vicious circle tends to arise due to chronic physical inactivity. The causes are psychological problems, treatment-related side-effects, and physical activity restrictions, which lead to insecurity and lack of motivation, followed by inactivity and isolation. The subsequent loss of physical fitness and other negative consequences increase immobility 
Citation: Baumann FT, Bieck O, Strunk M, Reimer N, Zopf EM, et al. (2018) Effects of a 6 Week Hike on Level of Physical Activity, Psychological Parameters and Quality of Life in Breast Cancer Survivors. J Cancer Sci Ther 10: 156-161. doi: 10.4172/1948-5956.1000538

\begin{tabular}{|c|c|c|c|c|c|c|}
\hline $\begin{array}{l}\text { EORTC QLQ-C30 } \\
\text { Parameters }\end{array}$ & $\begin{array}{c}\text { IG } \\
\text { (T3-Baseline) }\end{array}$ & $\begin{array}{c}\text { IG } \\
\text { (T2-Baseline) }\end{array}$ & $\begin{array}{c}\text { CG } \\
\text { (T3-Baseline) }\end{array}$ & $\begin{array}{c}\text { CG } \\
\text { (T2-Baseline) }\end{array}$ & $\begin{array}{c}\text { P-value } \\
\text { IG vs. CG } \\
\text { (T3-Baseline) }\end{array}$ & $\begin{array}{c}\text { P-value } \\
\text { IG vs. CG } \\
\text { (T2-Baseline) }\end{array}$ \\
\hline \multirow{2}{*}{$\begin{array}{c}\text { Global quality of life } \Delta \\
\text { SD } \\
\text { P-value }{ }^{F} \text { Intragroup }\end{array}$} & $\begin{array}{c}6.43 \\
\pm 20.54 \\
\end{array}$ & $\begin{array}{c}18.25 \\
\pm 15.94 \\
\end{array}$ & $\begin{array}{c}1.20 \\
\pm 5.75 \\
\end{array}$ & $\begin{array}{c}-4.66 \\
\pm 21.92 \\
\end{array}$ & 0.07 & 0.01 \\
\hline & 0.18 & 0.01 & 0.41 & 0.97 & & \\
\hline \multirow{2}{*}{$\begin{array}{c}\text { Physical functioning } \Delta \\
\text { SD } \\
\text { P-value }^{F} \text { Intragroup }\end{array}$} & $\begin{array}{c}10.01 \\
\pm 22.97 \\
\end{array}$ & $\begin{array}{c}14.60 \\
\pm 22.27 \\
\end{array}$ & $\begin{array}{c}4.76 \\
\pm 7.42 \\
\end{array}$ & $\begin{array}{c}0.01 \\
\pm 10.06 \\
\end{array}$ & 0.13 & 0.06 \\
\hline & 0.02 & 0.01 & 0.11 & 0.55 & & \\
\hline \multirow{2}{*}{$\begin{array}{c}\text { Role functioning } \Delta \\
\text { SD } \\
\text { P-value }{ }^{\mathrm{F}} \text { Intragroup }\end{array}$} & $\begin{array}{c}-0.76 \\
\pm 23.84 \\
\end{array}$ & $\begin{array}{c}7.14 \\
\pm 25.03 \\
\end{array}$ & $\begin{array}{c}11.90 \\
\pm 32.93 \\
\end{array}$ & $\begin{array}{c}-2.09 \\
\pm 20.97 \\
\end{array}$ & 0.54 & 0.93 \\
\hline & 0.82 & 0.21 & 0.41 & 0.92 & & \\
\hline \multirow{2}{*}{$\begin{array}{c}\text { Emotional functioning } \Delta \\
\text { SD } \\
\text { P-value }^{F} \text { Intragroup }\end{array}$} & $\begin{array}{c}9.47 \\
\pm 24.85 \\
\end{array}$ & $\begin{array}{c}23.01 \\
\pm 25.54\end{array}$ & $\begin{array}{c}1.20 \\
\pm 12.17 \\
\end{array}$ & $\begin{array}{c}-8.34 \\
\pm 25.27 \\
\end{array}$ & 0.08 & 0.01 \\
\hline & 0.12 & 0.01 & 0.58 & 0.05 & & \\
\hline \multirow{2}{*}{$\begin{array}{c}\text { Cognitive functioning } \Delta \\
\text { SD } \\
\text { P-value }^{\mathrm{F}} \text { Intragroup }\end{array}$} & $\begin{array}{c}10.59 \\
\pm 31.92 \\
\end{array}$ & $\begin{array}{c}13.48 \\
\pm 26.67 \\
\end{array}$ & $\begin{array}{c}11.89 \\
\pm 15.83 \\
\end{array}$ & $\begin{array}{c}8.33 \\
\pm 17.21 \\
\end{array}$ & 0.78 & 0.66 \\
\hline & 0.09 & 0.05 & 0.10 & 0.09 & & \\
\hline \multirow{2}{*}{$\begin{array}{c}\text { Social functioning } \Delta \\
\text { SD } \\
\text { P-value }{ }^{F} \text { Intragroup }\end{array}$} & $\begin{array}{c}11.36 \\
\pm 36.16 \\
\end{array}$ & $\begin{array}{c}20.01 \\
\pm 28.40 \\
\end{array}$ & $\begin{array}{c}14.29 \\
\pm 20.25 \\
\end{array}$ & $\begin{array}{c}1.04 \\
\pm 14.25 \\
\end{array}$ & 0.65 & 0.13 \\
\hline & 0.19 & 0.01 & 0.11 & 0.89 & & \\
\hline \multirow{2}{*}{$\begin{array}{c}\text { Fatigue } \Delta \\
\text { SD } \\
\text { P-value }^{F} \text { Intragroup }\end{array}$} & $\begin{array}{c}-1.51 \\
\pm 20.38 \\
\end{array}$ & $\begin{array}{c}-5.81 \\
\pm 19.14 \\
\end{array}$ & $\begin{array}{c}11.10 \\
\pm 14.33 \\
\end{array}$ & $\begin{array}{c}3.48 \\
\pm 17.07 \\
\end{array}$ & 0.30 & 0.60 \\
\hline & 0.50 & 0.29 & 0.08 & 0.42 & & \\
\hline \multirow{2}{*}{$\begin{array}{c}\text { Nausea and vomiting } \Delta \\
\text { SD } \\
\text { P-value } \text { Intragroup }^{-}\end{array}$} & $\begin{array}{c}2.27 \\
\pm 12.91 \\
\end{array}$ & $\begin{array}{r}-2.39 \\
\pm 5.99 \\
\end{array}$ & $\begin{array}{c}2.39 \\
\pm 6.31 \\
\end{array}$ & $\begin{array}{c}1.04 \\
\pm 4.18 \\
\end{array}$ & 0.94 & 0.06 \\
\hline & 0.48 & 0.08 & 0.32 & 0.32 & & \\
\hline \multirow{2}{*}{$\begin{array}{c}\text { Pain } \Delta \\
\text { SD } \\
\text { P-value }^{\mathrm{F}} \text { Intragroup } \\
\end{array}$} & $\begin{array}{c}10.60 \\
\pm 30.24 \\
\end{array}$ & $\begin{array}{c}15.08 \\
\pm 35.71 \\
\end{array}$ & $\begin{array}{c}-11.12 \\
\pm 25.07\end{array}$ & $\begin{array}{c}8.33 \\
\pm 21.94 \\
\end{array}$ & 0.39 & 0.60 \\
\hline & 0.14 & 0.10 & 0.29 & 0.18 & & \\
\hline \multirow{2}{*}{$\begin{array}{c}\text { Dyspnea } \Delta \\
\text { SD } \\
\text { P-value }^{\mathrm{F}} \text { Intragroup }\end{array}$} & $\begin{array}{c}1.52 \\
\pm 33.30 \\
\end{array}$ & $\begin{array}{c}-3.17 \\
\pm 23.34 \\
\end{array}$ & $\begin{array}{c}4.76 \\
\pm 12.59 \\
\end{array}$ & $\begin{array}{c}-2.09 \\
\pm 14.75 \\
\end{array}$ & 0.98 & 0.79 \\
\hline & 0.86 & 0.48 & 0.32 & 0.41 & & \\
\hline \multirow{2}{*}{$\begin{array}{c}\text { Sleep disturbance } \Delta \\
\text { SD } \\
\text { P-value } \text { Intragroup }^{-}\end{array}$} & $\begin{array}{c}7.57 \\
\pm 41.06 \\
\end{array}$ & $\begin{array}{c}0.01 \\
\pm 38.02 \\
\end{array}$ & $\begin{array}{r}14.30 \\
\pm 32.53 \\
\end{array}$ & $\begin{array}{c}-2.08 \\
\pm 35.44 \\
\end{array}$ & 0.95 & 0.49 \\
\hline & 0.53 & 0.87 & 0.20 & 0.94 & & \\
\hline \multirow{2}{*}{$\begin{array}{c}\text { Loss of appetite } \Delta \\
\text { SD } \\
\text { P-value } \text { Intragroup }\end{array}$} & $\begin{array}{c}1.51 \\
\pm 19.19 \\
\end{array}$ & $\begin{array}{c}-3.18 \\
\pm 14.54 \\
\end{array}$ & $\begin{array}{c}0.01 \\
\pm 0.00 \\
\end{array}$ & $\begin{array}{c}0.01 \\
\pm 12.16 \\
\end{array}$ & 0.88 & 0.89 \\
\hline & 0.85 & 0.26 & 1.00 & 1.00 & & \\
\hline \multirow{2}{*}{$\begin{array}{c}\text { Constipation } \Delta \\
\text { SD } \\
\text { P-value }{ }^{F} \text { Intragroup }\end{array}$} & $\begin{array}{c}7.57 \\
\pm 17.60 \\
\end{array}$ & $\begin{array}{c}3.18 \\
\pm 23.33 \\
\end{array}$ & $\begin{array}{c}4.77 \\
\pm 12.62 \\
\end{array}$ & $\begin{array}{c}2.08 \\
\pm 28.47 \\
\end{array}$ & 0.40 & 0.54 \\
\hline & 0.06 & 0.53 & 0.32 & 1.00 & & \\
\hline \multirow{2}{*}{$\begin{array}{c}\text { Diarrhoea } \Delta \\
\text { SD } \\
\text { P-value }^{F} \text { Intragroup }\end{array}$} & $\begin{array}{c}-7.57 \\
\pm 17.61 \\
\end{array}$ & $\begin{array}{c}-9.52 \\
\pm 15.43 \\
\end{array}$ & $\begin{array}{c}0.01 \\
\pm 0.01 \\
\end{array}$ & $\begin{array}{c}2.09 \\
\pm 22.67 \\
\end{array}$ & 0.14 & 0.09 \\
\hline & 0.06 & 0.02 & 1.00 & 0.46 & & \\
\hline \multirow{2}{*}{$\begin{array}{c}\text { Financial impact } \Delta \\
\text { SD } \\
\text { P-value } F \text { Intragroup }\end{array}$} & $\begin{array}{c}-12.11 \\
\pm 19.36 \\
\end{array}$ & $\begin{array}{c}-9.52 \\
\pm 15.42 \\
\end{array}$ & $\begin{array}{c}-4.76 \\
\pm 12.59 \\
\end{array}$ & $\begin{array}{c}-4.17 \\
\pm 26.87 \\
\end{array}$ & 0.01 & 0.03 \\
\hline & 0.01 & 0.02 & 0.32 & 0.65 & & \\
\hline
\end{tabular}

Table 2: Effects of a Long Hike on Quality of Life Outcomes (EORTC QLQ-C30) in Breast Cancer Survivors.

and again lead to insecurity [5]. Targeted, supervised and individualized physical activity interventions can break this vicious circle. The positive experience of being physically active can reduce insecurity, boost selfconfidence and reduce feeling of depression and anxiety. This in return can sustainably improve the physical activity levels of cancer patients as demonstrated in this study.

Observational studies have shown a correlation between regular physical activity and mortality/risk of recurrence [22-26], suggesting that the level of activity is a key factor in an exercise intervention study. In the present study an increase in total physical activity of $159.0 \%$ was recorded but the difference between groups was not significant after one year $(\mathrm{p}=0.15)$, probably due to the small sample size and large standard deviation. The control group did not change its physical activity level. It is worth noting that the overall physical activity level in the intervention group did not decrease significantly in the year following the hike. A physical and psychological challenge like a 6-week hike can increase the empowerment and thus the sense of personal responsibility of patients. They can recognize physical exercise as their own active contribution to recovery and integrate it into their daily lives over the long term.

A number of qualities of life (QLQ C30) outcomes improved significantly in the intervention group, with the greatest changes occurring during the hike. In fact, 11 out of the 16 subscales favored the intervention group after the hike. Notably, in three scales, patients 
Citation: Baumann FT, Bieck O, Strunk M, Reimer N, Zopf EM, et al. (2018) Effects of a 6 Week Hike on Level of Physical Activity, Psychological Parameters and Quality of Life in Breast Cancer Survivors. J Cancer Sci Ther 10: 156-161. doi: 10.4172/1948-5956.1000538

\begin{tabular}{|c|c|c|c|c|c|c|}
\hline $\begin{array}{l}\text { EORTC QLQ-BR23 } \\
\text { Parameters }\end{array}$ & $\begin{array}{c}\text { IG } \\
\text { (T3-Baseline) }\end{array}$ & $\begin{array}{c}\text { IG } \\
\text { (T2-Baseline) }\end{array}$ & $\begin{array}{c}\text { CG } \\
\text { (T3-Baseline) }\end{array}$ & $\begin{array}{c}\text { CG } \\
\text { (T2-Baseline) }\end{array}$ & $\begin{array}{c}\text { P-value } \\
\text { IG vs. CG } \\
\text { (T3-Baseline) }\end{array}$ & $\begin{array}{c}\text { P-value } \\
\text { IG vs. CG } \\
\text { (T2-Baseline) }\end{array}$ \\
\hline \multirow{2}{*}{$\begin{array}{c}\text { Body image } \Delta \\
\text { SD } \\
\text { P-value } \text { Intragroup }^{\text {Int }}\end{array}$} & $\begin{array}{c}12.88 \\
\pm 21.95 \\
\end{array}$ & $\begin{array}{c}13.50 \\
\pm 19.64 \\
\end{array}$ & $\begin{array}{c}11.90 \\
\pm 13.48 \\
\end{array}$ & $\begin{array}{c}13.01 \\
\pm 27.21 \\
\end{array}$ & 0.89 & 0.38 \\
\hline & 0.02 & 0.01 & 0.07 & 0.14 & & \\
\hline \multirow{2}{*}{$\begin{array}{c}\text { Future perspective } \Delta \\
\text { SD } \\
\text { P-value }{ }^{F} \text { Intragroup }\end{array}$} & $\begin{array}{c}21.22 \\
\pm 31.79 \\
\end{array}$ & $\begin{array}{c}36.52 \\
\pm 31.47 \\
\end{array}$ & $\begin{array}{c}4.77 \\
\pm 12.62 \\
\end{array}$ & $\begin{array}{c}6.26 \\
\pm 34.91 \\
\end{array}$ & 0.07 & 0.01 \\
\hline & 0.01 & 0.01 & 0.32 & 0.30 & & \\
\hline \multirow{2}{*}{$\begin{array}{c}\text { Sexual enjoyment } \Delta \\
\text { SD } \\
\text { P-value }{ }^{F} \text { Intragroup }\end{array}$} & $\begin{array}{l}-6.06 \\
\pm 24.43 \\
\end{array}$ & $\begin{array}{r}-23.80 \\
\pm 28.18 \\
\end{array}$ & $\begin{array}{c}11.12 \\
\pm 17.22 \\
\end{array}$ & $\begin{array}{c}-3.69 \\
\pm 20.03 \\
\end{array}$ & 0.12 & 0.02 \\
\hline & 0.29 & 0.01 & 0.18 & 1.00 & & \\
\hline \multirow{2}{*}{$\begin{array}{c}\text { Sexual functioning } \Delta \\
\text { SD } \\
\text { P-value }{ }^{\mathrm{F}} \text { Intragroup }\end{array}$} & $\begin{array}{c}0.75 \\
\pm 10.88 \\
\end{array}$ & $\begin{array}{c}25.44 \\
\pm 23.16 \\
\end{array}$ & $\begin{array}{c}0.01 \\
\pm 13.64 \\
\end{array}$ & $\begin{array}{c}-0.01 \\
\pm 18.91 \\
\end{array}$ & 0.75 & 0.01 \\
\hline & 0.90 & 0.01 & 1.00 & 0.95 & & \\
\hline \multirow{2}{*}{$\begin{array}{c}\text { Upset by hair loss } \Delta \\
\text { SD } \\
\text { P-value }{ }^{F} \text { Intragroup }\end{array}$} & $\begin{array}{c}7.57 \\
\pm 17.61 \\
\end{array}$ & $\begin{array}{c}-1.59 \\
\pm 12.79 \\
\end{array}$ & missing data & $\begin{array}{r}25.00 \\
\pm 31.93 \\
\end{array}$ & 0.96 & 0.15 \\
\hline & 0.06 & 0.56 & missing data & 0.18 & & \\
\hline \multirow{2}{*}{$\begin{array}{c}\text { Sys. therapy side effects } \Delta \\
\text { SD } \\
\text { P-valueF Intragroup }\end{array}$} & $\begin{array}{c}-6.50 \\
\pm 16.33 \\
\end{array}$ & $\begin{array}{l}-16.10 \\
\pm 17.07 \\
\end{array}$ & $\begin{array}{c}-4.74 \\
\pm 9.12 \\
\end{array}$ & $\begin{array}{c}0.32 \\
\pm 6.62 \\
\end{array}$ & 0.12 & 0.01 \\
\hline & 0.07 & 0.01 & 0.34 & 0.76 & & \\
\hline \multirow{2}{*}{$\begin{array}{c}\text { Arm symptoms } \Delta \\
\text { SD } \\
\text { P-value }^{\mathrm{F}} \text { Intragroup }\end{array}$} & $\begin{array}{r}-9.60 \\
\pm 25.96 \\
\end{array}$ & $\begin{array}{l}-19.57 \\
\pm 22.20 \\
\end{array}$ & $\begin{array}{l}-9.53 \\
\pm 24.37 \\
\end{array}$ & $\begin{array}{c}-4.16 \\
\pm 18.54 \\
\end{array}$ & 0.18 & 0.07 \\
\hline & 0.09 & 0.01 & 0.36 & 0.51 & & \\
\hline \multirow{2}{*}{$\begin{array}{c}\text { Breast symptoms } \Delta \\
\text { SD } \\
\text { P-value }^{F} \text { Intragroup }\end{array}$} & $\begin{array}{c}-4.94 \\
\pm 16.98 \\
\end{array}$ & $\begin{aligned} &-9.92 \\
& \pm 18.36 \\
&\end{aligned}$ & $\begin{array}{l}-5.94 \\
\pm 9.25 \\
\end{array}$ & $\begin{array}{l}-6.78 \\
\pm 9.72 \\
\end{array}$ & 0.62 & 0.97 \\
\hline & 0.15 & 0.03 & 0.13 & 0.01 & & \\
\hline
\end{tabular}

Table 3: Effects of a Long Hike on Breast Cancer Specific Concerns (EORTC QLQ-BR23) in Breast Cancer Survivors.

\begin{tabular}{|c|c|c|c|c|c|c|}
\hline $\begin{array}{c}\text { HADS } \\
\text { Parameters }\end{array}$ & $\begin{array}{c}\text { IG } \\
\text { (T3-Baseline) }\end{array}$ & $\begin{array}{c}\text { IG } \\
\text { (T2-Baseline) }\end{array}$ & $\begin{array}{c}\text { CG } \\
\text { (T3-Baseline) }\end{array}$ & $\begin{array}{c}\text { CG } \\
\text { (T2-Baseline) }\end{array}$ & $\begin{array}{c}\text { P-value } \\
\text { IG vs. CG } \\
\text { (T3-Baseline) }\end{array}$ & $\begin{array}{c}\text { P-value } \\
\text { IG vs. CG } \\
\text { (T2-Baseline) }\end{array}$ \\
\hline Depression $\Delta$ & -1.14 & -2.00 & -0.71 & 0.07 & & 0.27 \\
SD & \pm 2.88 & \pm 3.67 & \pm 2.69 & \pm 2.91 & 0.05 \\
\hline P-valueF Intragroup & 0.10 & 0.02 & 0.75 & 0.56 & & \\
\hline Anxiety $\Delta$ & -1.86 & -3.22 & -0.86 & 0.27 & 0.10 & \\
SD & \pm 3.58 & \pm 3.30 & \pm 1.35 & \pm 3.39 & 0.01 \\
P-valueF Intragroup & 0.04 & 0.01 & 0.13 & 0.69 & & \\
\hline
\end{tabular}

Abbreviations: IG=intervention group, CG=control group, $\mathrm{P}$-valueM=Mann-Whitney-U-Test, $\mathrm{P}$-valueF=Friedman-Test, baseline=start, T2=after hike, T3=1year post, $\Delta$ : Delta, SD: Standard Deviation

Table 4: Effects of a Long Hike on Anxiety and Depression (HADS) in Breast Cancer Survivors.

in the intervention group scored better than the average German population [18]. These scales include 'global health status' and 'physical functioning', highlighting the importance of this study. In 13 subscales and four out of the six individual items, patients in the intervention group scored better than the reference values of breast cancer survivors publish by Scott [19]. Thus, it can be summarized that the intervention delivers positive and sustainable results in terms of quality of life.

One year after the intervention, patients in the intervention group scored better than the reference values in three of the four function scales of the breast cancer specific EORTC QLQ-BR23 questionnaire. Thus, sustainable improvements in breast cancer-specific issues could be shown in part. The subjectively perceived improvements in quality of life could be caused by: altered hormone levels as a result of being outside surrounded by nature [20], improvements in mental stability due to being physically active [6], and a newly acquired autonomy that leads to self-assurance and personal responsibility [21].

This study was designed as a pilot project and therefore has some limitations. The results of this study need to be interpreted with caution due to the lack of randomization, the comparatively small sample size and the significant baseline difference in physical activity levels between the groups. Nevertheless, the results are very promising and have grounds to believe that a larger randomized controlled study would most likely generate similar effects. A long hike over multiple weeks requires preparation and a minimum level of fitness, however not necessarily any prior experience. This is the first study to suggest that a long hike is feasible and can improve physical activity levels and the quality of life in breast cancer survivors, who have completed primary treatment and have undergone a health check [27].

\section{Acknowledgments}

Freerk T. Baumann, Oliver Bieck, Nadine Reimer, Maximilian Strunk, Wilhelm Bloch \& Sabrina Han have no conflicts of interest to declare. No sources of funding were used to assist in the preparation of this manuscript.

\section{References}

1. Parkin DM, Bray F, Ferlay J, Pisani P (2005) Global cancer statistics, 2002. CA Cancer J Clin 55: 74-108.

2. Robert Koch-Institut (2015) Krebs in Deutschland. Berlin 2: 1. 
Citation: Baumann FT, Bieck O, Strunk M, Reimer N, Zopf EM, et al. (2018) Effects of a 6 Week Hike on Level of Physical Activity, Psychological Parameters and Quality of Life in Breast Cancer Survivors. J Cancer Sci Ther 10: 156-161. doi: 10.4172/1948-5956.1000538

3. Burgess C, Cornelius V, Love S, Graham J, Richards M, et al. (2005) Depression and anxiety in women with early breast cancer: Five-year observational cohort study. BMJ 330: 702.

4. Goldstein D, Bennett B, Friedlander M, Davenport T, Hickie I, et al. (2006) Fatigue states after cancer treatment occur both in association with, and independent of, mood disorder: A longitudinal study. BMC cancer 6: 240

5. Baumann FT (2007) Exercise, sports and cancer in the acute and rehabilitation phase: Historical background and state of the art. In Deimel H, Huber G, Pfeifer K, Schüle K (Eds.), New Active Ways in Prevention and Rehabilitation. Cologne: German doctors publishing house pp: 111-124.

6. Hollmann W, Strüder H (2009) Sports medicine. Basics for physical work, training and preventive medicine. Stuttgart: Schattauer-Verlag.

7. Harvey SB, Hotopf M, Overland S, Mykletun A (2010) Physical activity and common mental disorders. Br J Psychiatry 197: 357-364.

8. Ströhle A, Höfler M, Pfister H, Müller AG, Hoyer J, et al. (2007) Physical activity and prevalence and incidence of mental disorders in adolescents and young adults. Psychol Med 37: 1657-1666.

9. Blanchard CM, Denniston MM, Baker F, Ainsworth SR, Courneya KS, et al. (2003) Do adults change their lifestyle behaviors after a cancer diagnosis? Am J Health Behav 27: 246-256.

10. Irwin ML, Mc Tiernan A, Bernstein L, Gilliland FD, Baumgartner R, et al. (2004) Physical activity levels among breast cancer survivors. Med Sci Sports Exerc 36: $1484-1491$

11. Speck RM, Courneya KS, Mâsse LC, Duval S, Schmitz KH (2010) An update of controlled physical activity trials in cancer survivors: A systematic review and meta-analysis. J Cancer Surviv 4: 87-100.

12. Schmitz K (2011) Physical activity and breast cancer survivorship. Recent Results Cancer Res 186: 189-215.

13. Weineck $J$ (2007) Optimal training: Performance physiological training theory with special consideration of the children and youth training. Spitta Verlag.

14. Zintl F, Eisenhut A (2004) Endurance training: Basics, methods, training control. BLV publishing company 2: 1 .

15. Zugriff am 15.01.2014 unter [http://www.pilgern.ch/buch/karte/JakobswegEuropa-1000-web.jpg].
16. http://esport.dshs-koeln.de/459/1/Doktorarbeit_Sabrina_Han.pdf.

17. Lenhart $P$, Seibert W (2001) Functional exercise training: Recognize, eliminate and avoid muscular imbalances ( $6^{\text {th }}$ edition). Munich: Elsevier, Urban and Fischer Verlag.

18. Schwarz R, Hinz A (2001) Reference data for the quality of life questionnaire EORTC QLQ-C30 in the general German population. Eur J Cancer 37: 13451351.

19. Scott NW, Fayers PM, Aaronson NK, Bottomley A, Graeff AD, et al. (2008) EORTC QLQ-C30 Reference Values. Brüssel 2: 1.

20. Harte JL, Eifert GH (1995) The effects of running, environment, and attentional focus on athletes: Catecholamine and cortisol levels and mood. Psychophysiology 32: 49-54.

21. Ventegodt S, Flensborg-Madsen T, Andersen NJ, Merrick J (2008) Which factors determine our quality of life, health and ability? Results from a Danish population sample and the Copenhagen perinatal cohort. J Coll Physicians Surg Pak 18: 445-450

22. Holmes MD, Chen WY, Feskanich D, Kroenke CH, Colditz GA (2005) Physical activity and survival after breast cancer diagnosis. JAMA 293: 2479-2486.

23. Holick CN, Newcomb PA, Trentham-Dietz A, Titus-Ernstoff L, Bersch AJ, et al (2008) Physical activity and survival after diagnosis of invasive breast cancer. Cancer Epidemiol Biomarkers Prev 17: 379-386.

24. Irwin ML, Smith AW, Mc Tiernan A, Ballard-Barbash R, Cronin K, et al. (2008) Influence of pre- and postdiagnosis physical activity on mortality in breast cancer survivors: The health, eating, activity, and lifestyle study. J Clin Oncol 26: 3958-3964.

25. Sternfeld B, Weltzien E, Quesenberry CP, Castillo AL, Kwan M, et al. (2009) Physical activity and risk of recurrence and mortality in breast cancer survivors: Findings from the LACE study. Cancer Epidemiol Biomarkers Prev 18: 87-95.

26. Ibrahim EM, Al-Homaidh A (2011) Physical activity and survival after breast cancer diagnosis: Meta-analysis of published studies. Med Oncol 28: 753-765.

27. Bjelland I, Dahl AA, Haug TT, Neckelmann D (2002) The validity of the hospital anxiety and depression scale. An updated literature review. J Psychosom Res 52: 69-77. 